\title{
Impact of the TCF7L2 genotype on risk of hypoglycaemia and glucagon secretion during hypoglycaemia
}

Peter L Kristensen ${ }^{1}$, Ulrik Pedersen-Bjergaard ${ }^{1,2}$, Rikke Due-Andersen ${ }^{1,3}$, Thomas Høi-Hansen ${ }^{1,4}$, Lise Grimmeshave ${ }^{1,5}$, Valeriya Lyssenko ${ }^{6,7}$, Leif Groop ${ }^{7,8}$, Jens J Holst 2,9, Allan A Vaag ${ }^{2,10}$ and Birger Thorsteinsson ${ }^{1,2}$

'Department of Cardiology, Nephrology and Endocrinology, Nordsjællands Hospital, Hillerød, Denmark

${ }^{2}$ Faculty of Health and Medical Sciences, University of Copenhagen, Copenhagen, Denmark

${ }^{3}$ Lægerne på Ellemarksvej, Køge, Denmark

${ }^{4}$ Department of Cardiology, Herlev-Gentofte University Hospital, Herlev, Denmark

${ }^{5}$ Novo Nordisk A/S, Søborg, Denmark

${ }^{6}$ Steno Diabetes Center, Gentofte, Denmark

'Lund University Diabetes Centre, Skåne University Hospital, Malmø, Sweden

${ }^{8}$ Finnish Institute for Molecular Medicine (FIMM), Helsinki University, Helsinki, Finland

${ }^{9}$ Department of Biomedical Sciences, NNF Center for Basic Metabolic Research, The Panum Institute,

Copenhagen, Denmark

${ }^{10}$ Department of Endocrinology, Copenhagen University Hospital (Rigshospitalet), Copenhagen, Denmark

Correspondence

should be addressed

to $\mathrm{P}$ L Kristensen

Email

peter.lommer.kristensen.01@

regionh.dk

\begin{abstract}
Introduction: In healthy carriers of the T allele of the transcription factor 7-like 2 (TCF7L2), fasting plasma glucagon concentrations are lower compared with those with the $\mathrm{C}$ allele. We hypothesised that presence of the $\mathrm{T}$ allele is associated with a diminished glucagon response during hypoglycaemia and a higher frequency of severe hypoglycaemia (SH) in type 1 diabetes (T1DM).

Material and methods: This is a post hoc study of an earlier prospective observational study of SH and four mechanistic studies of physiological responses to hypoglycaemia. 269 patients with T1DM were followed in a one-year observational study. A log-linear negative binomial model was applied with events of SH as dependent variable and TCF7L2 alleles as explanatory variable. In four experimental studies including 65 people, TCF7L2 genotyping was done and plasma glucagon concentration during experimental hypoglycaemia was determined. Results: Incidences of SH were TT 0.54, TC 0.98 and CC 1.01 episodes per patient-year with no significant difference between groups. During experimental hypoglycaemia, the TCF7L2 polymorphism did not influence glucagon secretion.

Discussion: Patients with T1DM carrying the T allele of the TCF7L2 polymorphism do not exhibit diminished glucagon response during hypoglycaemia and are not at increased risk of severe hypoglycaemia compared with carriers of the $C$ allele.
\end{abstract}

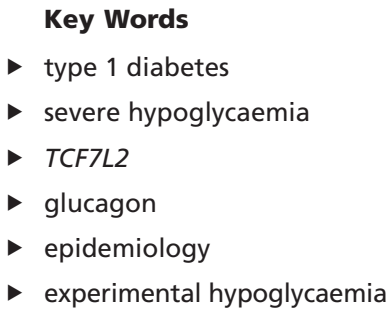

Endocrine Connections (2016) 5, 53-60

\section{Introduction}

Patients with type 1 diabetes are at daily risk of events of severe hypoglycaemia $(1,2,3,4,5,6,7)$. The distribution of these events is much skewed with a minority of subjects accounting for the vast majority of episodes $(1,2)$. Although important risk markers for severe hypoglycaemia like hormonal

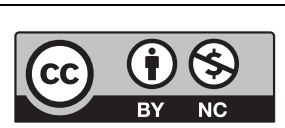

This work is licensed under a Creative Commons Attribution-NonCommercial 4.0 International License. 
counter-regulatory failure (8) and impaired hypoglycaemia awareness (6) have been identified, the highly varying inter-individual susceptibility to severe hypoglycaemia is largely unexplained. We previously speculated whether genetic factors are implicated and reported a high rate of severe hypoglycaemia in type 1 diabetic subjects carrying the common deletion-allele of the angiotensin-converting enzyme (ACE) gene that confers high enzyme activity in blood and tissues (9). This finding has been reproduced in six studies in five different populations by four independent research groups $(10,11,12,13,14,15)$. Schouwenberg and coworkers showed in healthy adults that possessing the Arg Arg (vs the Gly Gly) polymorphism of the $\beta 2$-adrenergic receptor may to some extent protect against the development of hypoglycaemia unawareness $(16,17)$, a major risk indicator of severe hypoglycaemia. In contrary Holstein et al. found no association between four genetic polymorphisms associated with insulin secretion and risk of severe hypoglycaemia in sulfonylurea-treated persons with type 2 diabetes (18).

Glucagon is a key player during the first-phase hormonal counter-regulation of hypoglycaemia (19). In people with type 1 diabetes, the glucagon secretory response to hypoglycaemia is initially diminished and subsequently lost within a few years of the onset of diabetes $(20,21)$. In the search for candidate risk genes for type 2 diabetes, the $\mathrm{T}$ allele of rs7903146 transcription factor 7-like 2 (TCF7L2) has been shown to confer the hitherto strongest association with type 2 diabetes, with a per allele odds ratio of $1.4(22,23,24)$. During the efforts to elucidate the underlying mechanism, a functional impact of the gene variant on glucagon concentrations has emerged. Thus, fasting glucagon concentrations were reported to be lower in healthy carriers of the $\mathrm{T}$ allele (approximately 30\% of the population (25)) compared with those with the $C$ allele $(26,27,28)$, whereas incremental glucagon secretion after a meal test does not differ between the alleles in normal, glucosetolerant subjects (29). The extent to which the TCF7L2 gene polymorphism influences glucagon secretion and/or risk of hypoglycaemia in people with type 1 diabetes is unknown.

We explored whether variants of the TCF7L2 gene influence the risk of severe hypoglycaemia in people with type 1 diabetes. The hypothesis was tested in a cohort of patients with type 1 diabetes previously followed for one year in an observational prospective study of the occurrence of severe hypoglycaemia (14). We also explored if variants of the TCF7L2 gene influence the secretion of glucagon during experimental hypoglycaemia in healthy adults and adult people with type 1 diabetes.

\section{Materials and methods}

\section{Epidemiological study}

This study is a post hoc study of blood samples collected during a prospective study designed to evaluate risk markers for severe hypoglycaemia in type 1 diabetes (14). Consecutive adult ( $>18$ years of age) outpatients with type 1 diabetes for more than two years were recruited by mail. Type 1 diabetes was defined by insulin treatment from the time of diagnosis and non-stimulated C-peptide $<300 \mathrm{pmol} / \mathrm{L}$ or stimulated (venous blood glucose concentration $>12 \mathrm{mmol} / \mathrm{L}$ ) C-peptide $<600 \mathrm{pmol} / \mathrm{L}$. Pregnant women and subjects on haemodialysis or suffering from concomitant malignant disease were excluded from participation. Clinical characteristics of the participating subjects appear from Table 1. Consent to participate was obtained from each subject after full explanation of the purpose and nature of all procedures used, and the study was approved by the Regional Committee on Biomedical Research Ethics. Results regarding the association between renin-angiotensin system components and risk of severe hypoglycaemia have been published elsewhere $(30,14)$.

At baseline, participants were characterised by their previous experience of hypoglycaemia. Episodes of severe hypoglycaemia were then reported prospectively for one year. The events were reported by telephone within $24 \mathrm{~h}$ and validated according to the triad of Whipple as described previously in detail (14). Only definite (all three criteria in Whipple's triad) and probable episodes (two criteria in Whipple's triad) of hypoglycaemia were classified as severe hypoglycaemia and used in the statistical analysis. These episodes were the primary endpoint. Two trained study nurses performed structured telephone interviews to establish the level of documentation, classify severity and explore circumstances of the incidents. Additionally, at the end of the follow-up period, severe hypoglycaemia was reported retrospectively by questionnaire, and in the case of missed reporting by telephone, interviews were carried out. Severe hypoglycaemia was defined as an episode at which the patient needs assistance from another person to restore the blood glucose level.

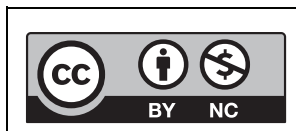

This work is licensed under a Creative Commons Attribution-NonCommercial 4.0 International License. 
Table 1 Patient characteristics in the total cohort and divided into TCF7L2 genotype.

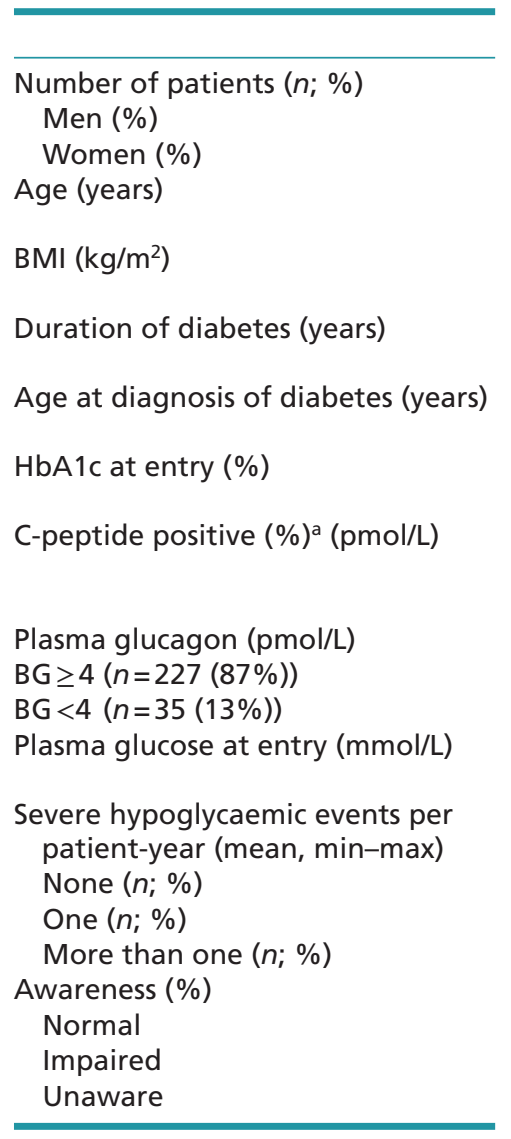

\begin{tabular}{|c|c|}
\hline All & TT \\
\hline 269 (100) & $13(4.8)$ \\
\hline $160(59.5)$ & $10(76.9)$ \\
\hline $109(40.5)$ & $3(23.1)$ \\
\hline $\begin{array}{c}45.1 \pm 13.4 \\
19-84\end{array}$ & $\begin{array}{c}46.6 \pm 10.6 \\
30-67\end{array}$ \\
\hline $25.1 \pm 3.65$ & $25.4 \pm 3.83$ \\
\hline $17.7-38.6$ & 19.4-33.9 \\
\hline $\begin{array}{c}20.9 \pm 11.8 \\
3-56\end{array}$ & $\begin{array}{c}21.2 \pm 9.7 \\
9-38\end{array}$ \\
\hline $\begin{array}{c}24.6 \pm 14.2 \\
0-70\end{array}$ & $\begin{array}{c}25.5 \pm 13.1 \\
2-43\end{array}$ \\
\hline $8.60 \pm 1.22$ & $9.1 \pm 1.1$ \\
\hline $5.2-14.0$ & 7.0-11.1 \\
\hline 59.9 & $8(62)$ \\
\hline $\begin{array}{c}65 \pm 91 \\
0-400\end{array}$ & $\begin{array}{c}48 \pm 55 \\
0-189\end{array}$ \\
\hline $4.8 \pm 3.4$ & $6.2 \pm 4.8$ \\
\hline $4.9 \pm 3.5$ & $6.6 \pm 5.3$ \\
\hline $4.5 \pm 3.2$ & $4.7 \pm 3.1$ \\
\hline $9.9 \pm 4.9$ & $8.8 \pm 5.2$ \\
\hline $0.9-24$ & $1-18$ \\
\hline $0.96,0-16$ & $0.54,0-5$ \\
\hline $179(66.5)$ & $11(84.6)$ \\
\hline $43(16.0)$ & 0 \\
\hline $47(17.5)$ & $2(14.4)$ \\
\hline 44 & 25.0 \\
\hline 44 & 50.0 \\
\hline 12 & 25.0 \\
\hline
\end{tabular}

\begin{tabular}{|c|}
\hline TC \\
\hline 89 (33.1) \\
\hline $48(53.9)$ \\
\hline $41(46.1)$ \\
\hline $\begin{array}{c}46.2 \pm 14.5 \\
20-84\end{array}$ \\
\hline $24.6 \pm 3.63$ \\
\hline $17.7-35.6$ \\
\hline $\begin{array}{c}20.5 \pm 12.3 \\
3-55\end{array}$ \\
\hline $\begin{array}{c}25.7 \pm 15.5 \\
0-60\end{array}$ \\
\hline $\begin{array}{l}8.5 \pm 1.3 \\
5.2-12.4\end{array}$ \\
\hline $56(63)$ \\
\hline $\begin{array}{c}84 \pm 106 \\
0-400\end{array}$ \\
\hline $4.9 \pm 3.6$ \\
\hline $4.9 \pm 3.5$ \\
\hline $5.6 \pm 5.0$ \\
\hline $10.2 \pm 4.7$ \\
\hline $0.9-23$ \\
\hline $0.97,0-15$ \\
\hline $55(61.8)$ \\
\hline $20(22.5)$ \\
\hline $14(15.7)$ \\
\hline 38.6 \\
\hline 50.5 \\
\hline 11.4 \\
\hline
\end{tabular}

\begin{tabular}{c}
\hline CC \\
\hline $143(53.2)$ \\
$85(59.4)$ \\
$58(40.6)$ \\
$44.2 \pm 13.3$ \\
$19-83$ \\
$25.4 \pm 3.68$ \\
$19.5-38.6$ \\
$20.5 \pm 11.5$ \\
$3-56$ \\
$23.8 \pm 13.8$ \\
$2-70$ \\
$8.7 \pm 1.2$ \\
$5.5-14.0$ \\
$77(54)$ \\
$50 \pm 77$ \\
$0-343$ \\
$4.7 \pm 3.3$ \\
$4.8 \pm 3.4$ \\
$4.1 \pm 2.3$ \\
$9.9 \pm 5.0$ \\
$1-24$ \\
$0.99,0-16$ \\
$95(66.4)$ \\
$21(14.7)$ \\
$27(18.9)$ \\
45.1 \\
42.3 \\
12.7 \\
\end{tabular}

\begin{tabular}{c}
\hline Missing genotype \\
\hline $24(8.9)$ \\
$17(70.8)$ \\
$7(29.2)$ \\
$45.3 \pm 11.6$ \\
$20-64$ \\
$25.0 \pm 3.52$ \\
$20.3-34.9$ \\
$20.3 \pm 13.0$ \\
$3-50$ \\
$20.3 \pm 13.0$ \\
$3-50$ \\
$8.38 \pm 1.05$ \\
$7.0-10.8$ \\
$20(83.3)$ \\
$90 \pm 115$ \\
$0-383$ \\
$4.7 \pm 2.9$ \\
$4.3 \pm 2.7$ \\
$6.0 \pm 3.5$ \\
$10.5 \pm 5.9$ \\
$2-25$ \\
$0.67,0-5$ \\
$18(75.0)$ \\
$2(8.3)$ \\
$4(16.7)$ \\
\end{tabular}

P

0.98

0.62

0.38

0.09

0.70

0.85

0.64

0.61

66.7

29.2

4.2

Values are mean (S.D.) or percentage when indicated. Frequency of severe hypoglycaemia is described by mean, min-max and distribution of zero, one or more episodes per year. We used one-way ANOVA, chi-square test and Kruskal-Wallis test as appropriate. $P$ values refer to comparisons between TCF7L2

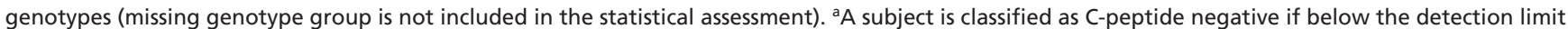
of $10 \mathrm{pmol} / \mathrm{L}$.

Hypoglycaemia awareness was estimated by a validated method based on self-reported ability to perceive hypoglycaemia (31). This method has previously been validated prospectively (32) and proven clinically relevant across language barriers in different populations $(2,33)$. The prevalence of unawareness corresponds to the prevalence of impaired awareness according to methods with only two categories $(31,5,6)$. Data on history of diabetes were extracted from medical records as described previously (14).

\section{Experimental study}

This study is a post hoc study of blood samples collected during four previously reported experimental studies. The first three were designed to evaluate the effect of activity in the renin-angiotensin system on hormonal, cardiac and cognitive function parameters during experimental hypoglycaemia $(34,35,36)$. The fourth study was a randomised controlled trial (RCT) designed to evaluate the effect of exogenous erythropoietin on cognitive function during hypoglycaemia in patients prone to severe hypoglycaemia (37). An overview of the four studies is available in Table 2. Specific details about the experimental protocol, including ethical issues and consent to participate, are reported elsewhere $(34,35,36,37)$.

\section{Laboratory analyses}

Radioimmunological determination of plasma glucagon concentrations was performed using a specific assay as described (38). The analytical detection limit was $1 \mathrm{pmol} / \mathrm{L}$ and intra- and inter-assay coefficients of variation were $<6 \%$ and $<15 \%$ respectively. Genotyping for TCF7L2 rs7903146 was performed using allelic discrimination performed with an ABI 7900 system (KBioscience, Hoddesdon, UK) as described (39). The genotype distribution obeyed Hardy-Weinberg equilibrium

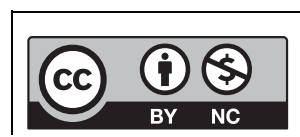

This work is licensed under a Creative Commons Attribution-NonCommercial 4.0 International License. 
Table 2 Characteristics of the four experimental studies.

\begin{tabular}{|c|c|c|c|c|}
\hline & Study 1 & Study 2 & Study 3 & Study 4 \\
\hline Reference & Hoi-Hansen et al. (35) & Due-Andersen et al. (36) & Bie-Olsen et al. (34) & Kristensen et al. (37) \\
\hline Study objective & $\begin{array}{l}\text { To study the effect of } \\
\text { high or low activity } \\
\text { of RAS on cognitive } \\
\text { function and } \\
\text { hormonal counter } \\
\text { regulation during } \\
\text { hypoglycaemia }\end{array}$ & $\begin{array}{l}\text { To study to the effect } \\
\text { of high or low } \\
\text { activity of RAS on the } \\
\text { QT interval and its } \\
\text { dynamics during } \\
\text { hypoglycaemia and } \\
\text { hypoxaemia }\end{array}$ & $\begin{array}{l}\text { To study the effect } \\
\text { of high or low } \\
\text { activity of RAS on } \\
\text { changes in cerebral } \\
\text { activity during } \\
\text { hypoglycaemia } \\
\text { measured with PET }\end{array}$ & $\begin{array}{l}\text { To study the effect } \\
\text { of treatment with } \\
\text { EPO on cognitive } \\
\text { function during } \\
\text { hypoglycaemia }\end{array}$ \\
\hline Population & $\begin{array}{l}\text { Type } 1 \text { diabetes: } 9 \text { with } \\
\text { high and } 9 \text { with low } \\
\text { activity in RAS }\end{array}$ & $\begin{array}{l}\text { Healthy adults: } 10 \text { with } \\
\text { high and } 10 \text { with low } \\
\text { activity in RAS }\end{array}$ & $\begin{array}{l}\text { Healthy adults: } 10 \text { with } \\
\text { high and } 10 \text { with low } \\
\text { activity in RAS }\end{array}$ & $\begin{array}{l}\text { Type } 1 \text { diabetes: } \\
\text { Prone to severe } \\
\text { hypoglycaemia }\end{array}$ \\
\hline Induction of hypoglycaemia & $\begin{array}{l}\text { Standardised } \\
\text { intravenous insulin } \\
\text { infusion. No glucose } \\
\text { was infused }\end{array}$ & $\begin{array}{l}\text { Subcutaneously } \\
\text { administered insulin }\end{array}$ & $\begin{array}{l}\text { Standardised } \\
\text { intravenous insulin } \\
\text { infusion. No glucose } \\
\text { was infused }\end{array}$ & $\begin{array}{l}\text { Intravenous } \\
\text { hypoglycaemic clamp }\end{array}$ \\
\hline$N$ & 18 & 20 & 20 & 11 \\
\hline $\begin{array}{l}\text { Mean plasma glucose } \\
\text { during hypoglycaemia, } \\
\text { mean (s.D.) (mmol/L) }\end{array}$ & $2.5(0.3)$ & $2.8(0.3)$ & $2.2(0.4)$ & $\begin{array}{l}2.2(0.1) \text { EPO-day } \\
2.2(0.2) \text { placebo-day }\end{array}$ \\
\hline $\begin{array}{l}\text { TCF7L2 polymorphism, } \\
\text { TT/TC/CC/U (\%) }\end{array}$ & 0/3/14/1 (0/17/78/5) & $3 / 8 / 7 / 2(19 / 38 / 33 / 10)$ & $3 / 6 / 11 / 0(15 / 30 / 55 / 0)$ & $3 / 4 / 3 / 1(27 / 37 / 27 / 9)$ \\
\hline $\begin{array}{l}\text { Baseline plasma glucagon } \\
\text { (normoglycaemia) mean } \\
\text { (s.D.) (nmol/L) }\end{array}$ & $7.1(1.9)$ & $6.9(2.2)$ & $14(3.7)$ & $4.2(0.7)$ \\
\hline $\begin{array}{l}\text { Peak plasma glucagon } \\
\text { (hypoglycaemia) mean } \\
\text { (s.D.) (nmol/L) }\end{array}$ & $8.5(2.9)$ & 28 (11) & $51(21)$ & $8.1(3.0)$ \\
\hline
\end{tabular}

EPO, erythropoietin; PET, positron emission tomography; RAS, renin-angiotensin system; $U$, undetermined genotyping.

$(P>0.05)$. HbA1c was measured spectrophotometrically (DCA-2000, Bayer; normal range 4.1-6.4\%). C-peptide levels were measured by radioimmunoassay (Autodelfia, Wallac Oy, Turku, Finland). Subjects were classified as being C-peptide negative if the value is below $10 \mathrm{pmol} / \mathrm{L}$ (detection limit of the assay). Measurements of HbA1c, $\mathrm{C}$-peptide and glucagon were done at the time of the primary studies, except for measurement of glucagon in the epidemiological study; genotyping was done post hoc. Blood for post hoc laboratory analysis was stored at $-80^{\circ} \mathrm{C}$ since the completion of the primary studies.

\section{Statistical analyses}

No participant appears twice in the epidemiological study, or the experimental studies, but some participants were included in both the epidemiological study and an experimental study.

Epidemiological study As the distribution of episodes of severe hypoglycaemia (primary endpoint) is very skewed $(1,2)$, a log-linear negative binomial regression model was applied (SPSS: Analyze $>$ Generalized
Linear Models $>$ Negative Binomial) with events of severe hypoglycaemia as dependent variable. First, we did univariate analyses with plasma glucagon or TCF7L2 genotype as explanatory variables. Secondly, we performed a multivariate analysis with adjustment for

Table 3 Regression model with episodes of severe hypoglycaemia as dependent variable.

\begin{tabular}{|c|c|c|c|c|}
\hline & \multicolumn{4}{|c|}{$\begin{array}{l}\text { Change in episodes of SH per year per change } \\
\text { in explanatory variable }\end{array}$} \\
\hline & Univariate & $P$ & Multivariate & $P$ \\
\hline \multicolumn{5}{|l|}{ Variable } \\
\hline $\begin{array}{l}\text { Glucagon } \\
\text { (pmol/L) }\end{array}$ & $0.0(-0.0$ to 0.0$)$ & 0.83 & $0.0(0.0-0.0)$ & 0.96 \\
\hline \multicolumn{5}{|c|}{ TCF7L2 genotype } \\
\hline TT & $-0.4(-1.0$ to 0.3$)$ & 0.26 & $-0.2(-0.8$ to 0.3$)$ & 0.42 \\
\hline TC & $-0.0(-0.2$ to 0.2$)$ & 0.89 & $-0.0(-0.2$ to 0.1$)$ & 0.71 \\
\hline $\mathrm{CC}$ & - & & - & \\
\hline
\end{tabular}

Regression coefficients (95\% confidence intervals) for concentrations of plasma glucagon and the TCF7L2 genotype (explanatory variables) in a generalized linear model (negative binomial distribution) with episodes of severe hypoglycaemia (SH) as dependent variable. The multivariate analyses are adjusted for age, duration of diabetes, C-peptide status, hypoglycaemia awareness status, $\mathrm{HbA} 1 \mathrm{c}$ and serum ACE activity at baseline. The CC genotype serves as reference and is set to zero. ACE, Angiotensin-converting enzyme.

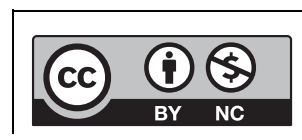

This work is licensed under a Creative Commons Attribution-NonCommercial 4.0 International License. 
age, duration of diabetes, C-peptide status, hypoglycaemia awareness status and HbA1c and serum ACE at baseline. Comparisons between the subgroups in Table 1 were done by one-way ANOVA, Kruskal-Wallis test or chi-square tests as appropriate.

Experimental study We report fasting plasma glucagon concentration at baseline (normoglycaemia) and during experimental hypoglycaemia. Baseline plasma glucagon concentration is calculated as the mean of two baseline values. In the RCT (37), baseline values from both arms of the cross-over study were pooled. Only data from the hypoglycaemic (and not normoglycaemic (control) or hypoxic) study days in the three other studies $(34,35$, 36) were included. Peak values of glucagon concentration were defined as the highest glucagon concentration measured during the hypoglycaemic clamp. We used a linear mixed model (SPSS: Analyze $>$ Mixed Models $>$ Linear $>$ Continue) to compare the glucagon concentration during the experiments, the primary endpoint, in the three TCF7L2 polymorphism groups. Person-id was set as a random factor, and experimental condition (hypoglycaemia vs normoglycaemia), diabetes status (type 1 diabetes vs healthy) and TCF7L2 polymorphism as fixed factors. Potentially, an interaction among diabetes status, experimental condition and TCF7L2 polymorphism was present. Therefore, interaction terms were constructed and included as fixed factors: experimental condition $\times$ diabetes status, experimental condition $\times$ TCF7L2 polymorphism and diabetes status $\times$ TCF7L2 polymorphism.

Calculations were performed with SPSS software package (version 11.0). We considered a two-tailed $P$ value of less than 0.05 statistically significant.

\section{Results}

\section{Epidemiological study}

A total of 235 episodes of severe hypoglycaemia $(0.96$ episodes per patient-year) were reported by 90 of 269 patients (37\%). The TCF7L2 alleles could be detected in 245 of 269 patients (91\%) and were distributed as follows: TT 5\%, TC 36\% and CC 59\%. The mean incidences of severe hypoglycaemic episodes were $0.54(0-5)$ in the TT group, $0.97(0-15)$ in the TC group and $0.99(0-16)$ episodes per patient-year in the CC group (Table 1).

The risk of severe hypoglycaemia was associated neither with the plasma glucagon concentration nor

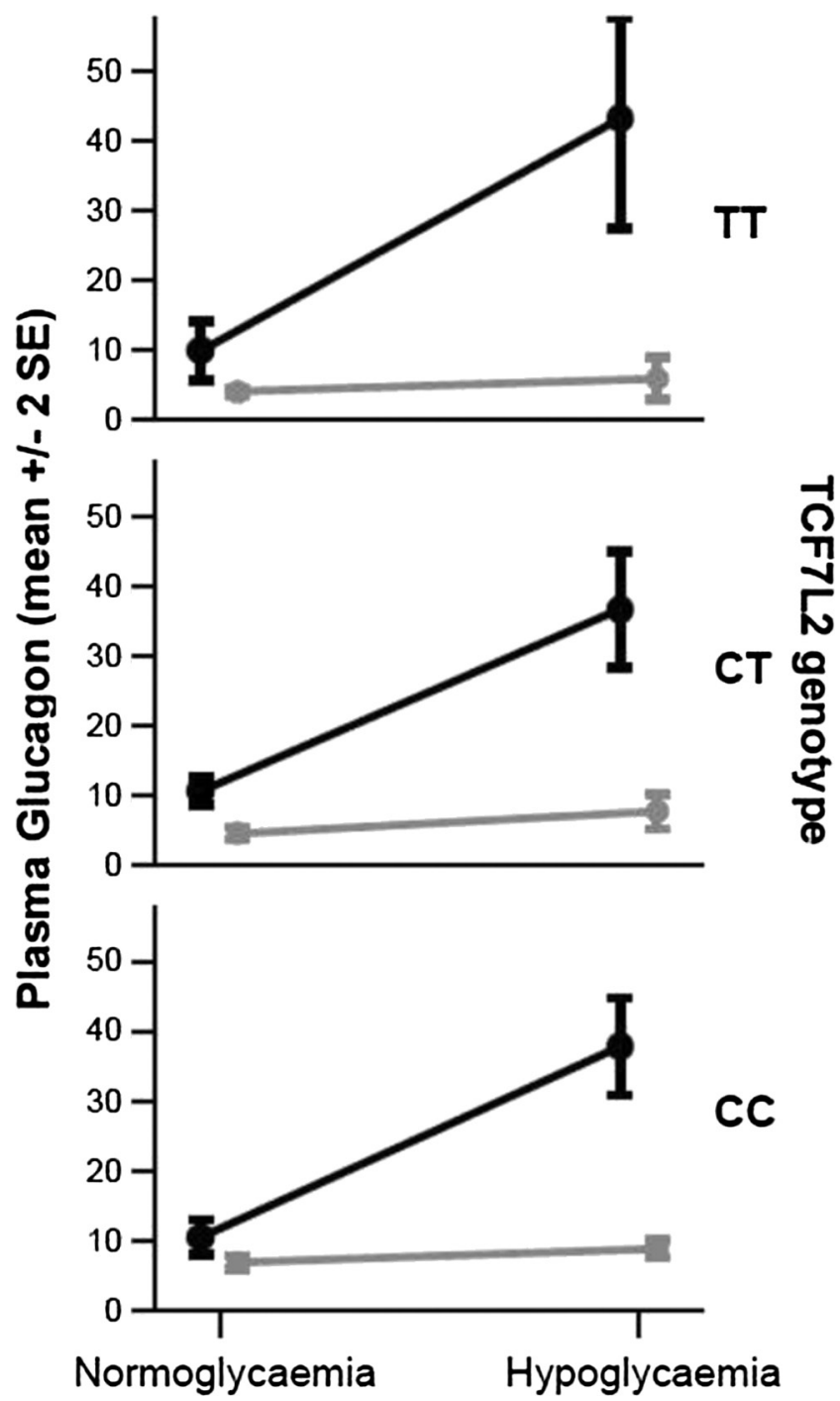

Figure 1

Mean values of plasma glucagon in 38 healthy adults (black lines) and 27 people with type 1 diabetes (grey lines) divided according to the TCF7L2 genotypes TT, CT and CC before (normoglycaemia) and during experimental hypoglycaemia.

with the TCF7L2 genotype in univariate or multivariate regression analyses (Table 3 ). The hypoglycaemia awareness status was not different in the three TCF7L2 genotype groups ( $P=0.15$, chi-square test) (Table 1$)$. Mean plasma glucagon concentrations ( \pm 1 S.D.) were $6.2 \pm 4.8 \mathrm{pmol} / \mathrm{L}$, $4.9 \pm 3.6 \mathrm{pmol} / \mathrm{L}$ and $4.7 \pm 3.3 \mathrm{pmol} / \mathrm{L}$ in the TT, TC and CC groups, respectively $(P=0.70 ;$ Kruskal-Wallis test) (Table 1). Plasma glucagon concentrations did not differ between subjects with blood glucose concentrations equal to or above vs below $4 \mathrm{mmol} / \mathrm{L}$ at the time of glucagon measurement $(P=0.86)$, data not shown.
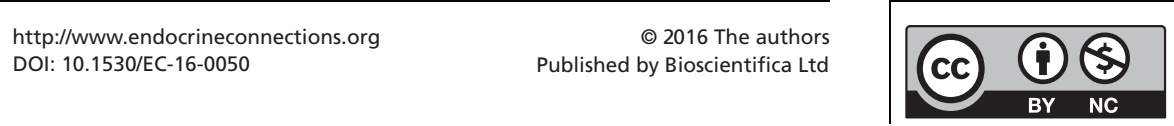


\section{Experimental study}

Sixty-nine participants took part in the four studies. Among these, 40 were healthy adults and 29 had type 1 diabetes. The TCF7L2 alleles could be detected in 65 (38 healthy adults and 27 with type 1 diabetes) participants and were distributed as follows: TT 15\%, TC $32 \%$ and CC $53 \%$. In the mixed model, there was no effect of TCF7L2 polymorphism on plasma glucagon concentrations ( $P=0.85$ for main effect, $P=0.74$ for the interaction term diabetes status $\times$ TCF7L2 polymorphism and $P=0.47$ for the interaction term experimental condition and $\times$ TCF7L2 polymorphism). The interaction term diabetes status $\times$ experimental condition strongly affected glucagon concentration $\left(F=99.6, \quad P=2.0 \times 10^{-14}\right)$. The estimated means of plasma glucagon in healthy adults were 11 (95\% C.I. 7.5-14) nmol/L during normoglycaemia and 39 (36-42) nmol/L during hypoglycaemia. The estimated means of glucagon in participants with type 1 diabetes were $5.0(0.9-9.0) \mathrm{nmol} / \mathrm{L}$ during normoglycaemia and 8.3 (4.0-13) nmol/L during hypoglycaemia (Fig. 1).

\section{Discussion}

We explored if variants of the TCF7L2 gene influence the risk of severe hypoglycaemia in a cohort of 245 people with type 1 diabetes followed for one year in an observational prospective study of the occurrence of severe hypoglycaemia and risk markers for the events. In univariate and multivariate analyses, we found no significant relationship between the distribution of TCF7L2 alleles and the risk of severe hypoglycaemia. Neither did we find any relationship between concentration of random measurements of plasma glucagon on one side and the risk of severe hypoglycaemia on the other.

Healthy carriers of the T allele of the TCF7L2 gene have been reported to have lower fasting glucagon concentrations compared with carriers of the C allele $(26,27,28)$. Therefore, we hypothesised that carriers of the $\mathrm{T}$ allele could have a lower glucagon secretory capacity than carriers of the $\mathrm{C}$ allele, leading to diminished plasma glucagon responses during hypoglycaemia and thereby an increased risk of $\mathrm{SH}$. We tested this in 38 healthy adults and 27 persons with type 1 diabetes and found no evidence supporting our a priori study hypothesis.

The strength of the epidemiological study is the large number of well-described patients with type 1 diabetes followed prospectively for a relatively long time. Moreover, thorough gathering of data regarding episodes of severe hypoglycaemia (primary endpoint) and using a statistical model that deals with the much skewed distribution of episodes of severe hypoglycaemia is an advantage. Therefore, we find the results regarding the primary endpoint reliable. It is a possible limitation of the study that episodes of SH may be underreported, especially nocturnal episodes and especially by patients with recurrent episodes (32). Another limitation is the non-standardised measurement of plasma glucagon levels performed in non-fasting blood samples stored for several years. This may lead to both pre-analytical and analytical variation in plasma glucagon concentrations, thereby underestimating any possible role of glucagon. Moreover, our post hoc study was done in a population of patients with relatively long-standing type 1 diabetes, which is associated with a reduced secretory glucagon response to hypoglycaemia $(20,21)$. Potential differences in plasma glucagon levels due to TCF7L2 gene variations may be blurred by this.

The strength of the experimental studies is the relatively large number of persons studied during controlled hypoglycaemia. However, the methods to obtain hypoglycaemia and the subjects in the four studies were different, making pooling of data questionable. Nevertheless, we believe that the potential problem of using different methods to obtain hypoglycaemia in this post hoc study is insignificant as, in all four studies, a robust hypoglycaemic stimulus was obtained. Moreover, a possible influence of the TCF7L2 polymorphism should not depend on the method of inducing hypoglycaemia. The different subject characteristics of the populations in the four studies probably leads to greater variation in plasma glucagon concentrations rendering possible genotyperelated differences in plasma glucagon concentration more difficult to find, increasing the risk of a statistical type 2 error regarding the potential impact of the TCF7L2 polymorphism on plasma glucagon levels. However, analysing delta values of glucagon separately in participants with or without diabetes did not change the conclusions of this post hoc study.

The only hitherto consistently reported biomarkers of severe hypoglycaemia in type 1 diabetes are undetectable C-peptide levels $(9,4)$, low HbA1c $(40,41,42)$ and high serum ACE activity $(10,11,12,13$, $14,15)$. However, these markers only explain a minor proportion of the risk variation between subjects. We conclude that determination of TCF7L2 gene variations http://www.endocrineconnections.org DOI: 10.1530/EC-16-0050
(C) 2016 The authors Published by Bioscientifica Ltd
This work is licensed under a Creative Commons Attribution-NonCommercial 4.0 International License. 
and random measurements of plasma glucagon do not help predict episodes of severe hypoglycaemia in type 1 diabetes. We also conclude that glucagon secretion during experimental hypoglycaemia in patients with and without type 1 diabetes is not affected by the TCF7L2 gene polymorphism. These results add up to the complicated picture of glucagon function in glucose homeostasis. Although the TCF7L2 gene polymorphism seems to affect glucagon secretion during normoglycaemia and hyperglycaemia in normal man and patients with type 2 diabetes, the response to hypoglycaemia both in normal man and patients with type 1 diabetes is unaffected by this polymorphism. However, due to the limitations of the study (pre-analytical and analytical variation in plasma glucagon concentrations), we need studies to validate the effect of TCF7L2 genotypes on glucagon levels and risk of severe episodes of hypoglycaemia in type 1 diabetes. Finding robust risk factors for the identification of patients at high risk of severe hypoglycaemia would be beneficial in daily diabetes management. Moreover, it could improve the understanding of the physiology of hypoglycaemia.

\section{Declaration of interest}

The authors declare that there is no conflict of interest that could be perceived as prejudicing the impartiality of the research reported.

\section{Funding}

This research did not receive any specific grant from any funding agency in the public, commercial or not-for-profit sector.

\section{Acknowledgements}

The authors thank research nurses $P$ Banck and $T$ Larsen for careful handling of patients and data. The staff at the outpatient diabetes clinic, at the Department of Cardiology, Nephrology and Endocrinology, Nordsjællands Hospital, Hillerød, is acknowledged for their cooperation during patient recruitment.

\section{References}

1 Kristensen PL, Hansen LS, Jespersen MJ, Pedersen-Bjergaard U, Beck-Nielsen H, Christiansen JS, Norgaard K, Perrild H, Parving HH, Thorsteinsson B, et al. Insulin analogues and severe hypoglycaemia in type 1 diabetes. Diabetes Research and Clinical Practice 201296 17-23. (doi:10.1016/j.diabres.2011.10.046)

2 Pedersen-Bjergaard U, Pramming S, Heller SR, Wallace TM, Rasmussen AK, Jorgensen HV, Matthews DR, Hougaard P \& Thorsteinsson B. Severe hypoglycaemia in 1076 adult patients with type 1 diabetes: influence of risk markers and selection. Diabetes Metabolism Research and Reviews 200420 479-486. (doi:10.1002/ dmrr.482)

3 ter Braak EW, Appelman AM, van de LM, Stolk RP, van Haeften TW \& Erkelens DW. Clinical characteristics of type 1 diabetic patients with and without severe hypoglycemia. Diabetes Care 200023 1467-1471. (doi:10.2337/diacare.23.10.1467)
4 Muhlhauser I, Overmann H, Bender R, Bott U \& Berger M. Risk factors of severe hypoglycaemia in adult patients with Type I diabetes - a prospective population based study. Diabetologia 199841 1274-1282. (doi:10.1007/s001250051065)

5 Clarke WL, Cox DJ, Gonder-Frederick LA, Julian D, Schlundt D $\&$ Polonsky W. Reduced awareness of hypoglycemia in adults with IDDM. A prospective study of hypoglycemic frequency and associated symptoms. Diabetes Care 199518 517-522. (doi:10.2337/ diacare.18.4.517)

6 Gold AE, MacLeod KM \& Frier BM. Frequency of severe hypoglycemia in patients with type I diabetes with impaired awareness of hypoglycemia. Diabetes Care 199417 697-703. (doi:10.2337/ diacare.17.7.697)

7 MacLeod KM, Hepburn DA \& Frier BM. Frequency and morbidity of severe hypoglycaemia in insulin-treated diabetic patients. Diabetic Medicine 199310 238-245. (doi:10.1111/j.1464-5491.1993.tb00051.x)

8 Cryer PE. Hypoglycaemia: the limiting factor in the glycaemic management of Type I and Type II diabetes. Diabetologia 200245 937-948. (doi:10.1007/s00125-002-0822-9)

9 Pedersen-Bjergaard U, Gerholm-Larsen B, Pramming S, Hougaard P \& Thorsteinsson B. Activity of angiotensin-converting enzyme and risk of severe hypoglycaemia in type 1 diabetes mellitus. Lancet 2001357 1248-1253. (doi:10.1016/S0140-6736(00)04405-6)

10 Johannesen J, Svensson J, Bergholdt R, Eising S, Gramstrup H, Frandsen E, Dick-Nielsen J, Hansen L, Pociot F \& Mortensen HB. Hypoglycemia, S-ACE and ACE genotypes in a Danish nationwide population of children and adolescents with type 1 diabetes. Pediatric Diabetes 201112 100-106. (doi:10.1111/j.1399-5448.2010.00660.x)

11 Faerch L, Pedersen-Bjergaard U \& Thorsteinsson B. High serum ACE activity predicts severe hypoglycaemia over time in patients with type 1 diabetes. Scandinavian Journal of Clinical and Laboratory Investigation 201171 620-624. (doi:10.3109/00365513.2011.604132)

12 Nielsen LR, Pedersen-Bjergaard U, Thorsteinsson B, Boomsma F, Damm P \& Mathiesen ER. Severe hypoglycaemia during pregnancy in women with type 1 diabetes: possible role of renin-angiotensin system activity? Diabetes Research and Clinical Practice 2009 84 61-67. (doi:10.1016/j.diabres.2009.01.006)

13 Zammitt NN, Geddes J, Warren RE, Marioni R, Ashby JP \& Frier BM. Serum angiotensin-converting enzyme and frequency of severe hypoglycaemia in Type 1 diabetes: does a relationship exist? Diabetic Medicine 200724 1449-1454. (doi:10.1111/j.14645491.2007.02263.x)

14 Pedersen-Bjergaard U, Agerholm-Larsen B, Pramming S, Hougaard P \& Thorsteinsson B. Prediction of severe hypoglycaemia by angiotensinconverting enzyme activity and genotype in type 1 diabetes. Diabetologia 200346 89-96. (doi:10.1007/s00125-002-0969-4)

15 Nordfeldt S \& Samuelsson U. Serum ACE predicts severe hypoglycemia in children and adolescents with type 1 diabetes. Diabetes Care 200326 274-278. (doi:10.2337/diacare.26.2.274)

16 Schouwenberg BJ, Veldman BA, Spiering W, Coenen MJ, Franke B, Tack CJ, de Galan BE \& Smits P. The Arg16Gly variant of the beta2adrenergic receptor predisposes to hypoglycemia unawareness in type 1 diabetes mellitus. Pharmacogenetics and Genomics 200818 369-372. (doi:10.1097/FPC.0b013e3282f70481)

17 Schouwenberg BJ, Smits P, Tack CJ \& de Galan BE. The effect of antecedent hypoglycaemia on beta(2)-adrenergic sensitivity in healthy participants with the Arg16Gly polymorphism of the beta(2)adrenergic receptor. Diabetologia 201154 1212-1218. (doi:10.1007/ s00125-011-2062-3)

18 Holstein JD, Patzer O, Korner A, Stumvoll M, Kovacs P \& Holstein A Genetic variants in GCKR, GIPR, ADCY5 and VPS13C and the risk of severe sulfonylurea-induced hypoglycaemia in patients with type 2 diabetes. Experimental Clinical Endocrinology and Diabetes 2013121 54-57. (doi:10.1055/s-0032-1321834)

19 Kerr D \& Richardson T. Counterregulatory deficiences in diabetes. In Hypoglycaemia in Clinical Diabetes, edn 2, ch 6, pp 121-140. 
Eds B Frier \& M Fisher. Chichester, England, UK: John Wiley \& Sons Ltd, 2007.

20 Bolli G, De FP, Compagnucci P, Cartechini MG, Angeletti G, Santeusanio F, Brunetti P \& Gerich JE. Abnormal glucose counterregulation in insulin-dependent diabetes mellitus. Interaction of anti-insulin antibodies and impaired glucagon and epinephrine secretion. Diabetes 198332 134-141. (doi:10.2337/ diab.32.2.134)

21 Gerich JE, Langlois M, Noacco C, Karam JH \& Forsham PH. Lack of glucagon response to hypoglycemia in diabetes: evidence for an intrinsic pancreatic alpha cell defect. Science 1973182 171-173. (doi:10.1126/science.182.4108.171)

22 Smith RJ, Nathan DM, Arslanian SA, Groop L, Rizza RA \& Rotter JI. Individualizing therapies in type 2 diabetes mellitus based on patient characteristics: what we know and what we need to know. Journal of Clinical Endocrinology and Metabolism 201095 1566-1574. (doi:10.1210/jc.2009-1966)

23 Pearson ER. Translating TCF7L2: from gene to function. Diabetologia 200952 1227-1230. (doi:10.1007/s00125-009-1356-1)

24 Helgason A, Palsson S, Thorleifsson G, Grant SF, Emilsson V, Gunnarsdottir S, Adeyemo A, Chen Y, Chen G, Reynisdottir I, et al. Refining the impact of TCF7L2 gene variants on type 2 diabetes and adaptive evolution. Nature Genetics 200739 218-225. (doi:10.1038/ ng1960)

25 Cauchi S, Choquet H, Gutierrez-Aguilar R, Capel F, Grau K, Proenca C, Dina C, Duval A, Balkau B, Marre M, et al. Effects of TCF7L2 polymorphisms on obesity in European populations. Obesity 200816 476-482. (doi:10.1038/oby.2007.77)

26 Alibegovic AC, Sonne MP, Hojbjerre L, Hansen T, Pedersen O, van HG, Holst JJ, Stallknecht B, Dela F \& Vaag A. The T-allele of TCF7L2 rs7903146 associates with a reduced compensation of insulin secretion for insulin resistance induced by 9 days of bed rest. Diabetes 201059 836-843. (doi:10.2337/db09-0918)

27 Pilgaard K, Jensen CB, Schou JH, Lyssenko V, Wegner L, Brons C, Vilsboll T, Hansen T, Madsbad S, Holst JJ, et al. The T allele of rs7903146 TCF7L2 is associated with impaired insulinotropic action of incretin hormones, reduced $24 \mathrm{~h}$ profiles of plasma insulin and glucagon, and increased hepatic glucose production in young healthy men. Diabetologia 200952 1298-1307. (doi:10.1007/s00125009-1307-x)

28 Daniele G, Gaggini M, Comassi M, Bianchi C, Basta G, Dardano A, Miccoli R, Mari A, Gastaldelli A \& Prato SD. glucose metabolism in high risk subjects for type 2 diabetes carrying the rs7903146 TCF7L2 gene variant. Journal of Clinical Endocrinology and Metabolism 2015 100 E1160-E1167. (doi:10.1210/jc.2015-1172)

29 Gjesing AP, Kjems LL, Vestmar MA, Grarup N, Linneberg A, Deacon CF, Holst JJ, Pedersen O \& Hansen T. Carriers of the TCF7L2 rs7903146 TT genotype have elevated levels of plasma glucose, serum proinsulin and plasma gastric inhibitory polypeptide (GIP) during a meal test. Diabetologia 201154 103-110. (doi:10.1007/s00125-0101940-4)

30 Pedersen-Bjergaard U, Dhamrait SS, Sethi AA, Frandsen E, Nordestgaard BG, Montgomery HE, Pramming S, Hougaard P \& Thorsteinsson B. Genetic variation and activity of the renin-angiotensin system and severe hypoglycemia in type 1 diabetes. American Journal of Medicine 2008121 246-248. (doi:10.1016/j.amjmed.2007.12.002)

31 Hoi-Hansen T, Pedersen-Bjergaard U \& Thorsteinsson B. Classification of hypoglycemia awareness in people with type 1 diabetes in clinical practice. Journal of Diabetes and its Complications 201024 392-397. (doi:10.1016/j.jdiacomp.2009.07.006)

32 Pedersen-Bjergaard U, Pramming S \& Thorsteinsson B. Recall of severe hypoglycaemia and self-estimated state of awareness in type 1 diabetes. Diabetes Metabolism Research and Reviews 200319 232-240. (doi:10.1002/dmrr.377)

33 Ostenson CG, Geelhoed-Duijvestijn P, Lahtela J, Weitgasser R, Markert JM \& Pedersen-Bjergaard U. Self-reported non-severe hypoglycaemic events in Europe. Diabetic Medicine 201431 92-101. (doi:10.1111/dme.12261)

34 Bie-Olsen LG, Kjaer TW, Pedersen-Bjergaard U, Lonsdale MN, Holst JJ, Law I \& Thorsteinsson B. Changes of cognition and regional cerebral activity during acute hypoglycemia in normal subjects: a H2 $15 \mathrm{O}$ positron emission tomographic study. Journal of Neuroscience Research 200987 1922-1928. (doi:10.1002/jnr.22002)

35 Hoi-Hansen T, Pedersen-Bjergaard U, Andersen RD, Kristensen PL, Thomsen C, Kjaer T, Hogenhaven H, Smed A, Holst JJ, Dela F, et al. Cognitive performance, symptoms and counter-regulation during hypoglycaemia in patients with type 1 diabetes and high or low renin-angiotensin system activity. Journal of the Renin-Angiotensin-Aldosterone System 200910 216-229. (doi:10.1177/1470320309343007)

36 Due-Andersen R, Hoi-Hansen T, Olsen NV, Larroude CE, Kanters JK, Boomsma F, Pedersen-Bjergaard U \& Thorsteinsson B. Cardiac repolarization during hypoglycaemia and hypoxaemia in healthy males: impact of renin-angiotensin system activity. Europace $2008 \mathbf{1 0}$ 219-226. (doi:10.1093/europace/eum286)

37 Kristensen PL, Pedersen-Bjergaard U, Kjaer TW, Olsen NV, Dela F, Holst JJ, Faber J, Tarnow L \& Thorsteinsson B. Influence of erythropoietin on cognitive performance during experimental hypoglycemia in patients with type 1 diabetes mellitus: a randomized cross-over trial. PLoS ONE 20138 e59672. (doi:10.1371/journal. pone.0059672)

38 Holst JJ. Molecular heterogeneity of glucagon in normal subjects and in patients with glucagon-producing tumours. Diabetologia 198324 359-365. (doi:10.1007/bf00251825)

39 Lyssenko V, Lupi R, Marchetti P, Del GS, Orho-Melander M, Almgren P, Sjogren M, Ling C, Eriksson KF, Lethagen AL, et al. Mechanisms by which common variants in the TCF7L2 gene increase risk of type 2 diabetes. Journal of Clinical Investigations $2007 \mathbf{1 1 7}$ 2155-2163. (doi:10.1172/JCI30706)

40 Allen C, LeCaire T, Palta M, Daniels K, Meredith M \& D'Alessio DJ. Risk factors for frequent and severe hypoglycemia in type 1 diabetes. Diabetes Care 200124 1878-1881. (doi:10.2337/diacare. 24.11.1878)

41 Hypoglycemia in the diabetes control and complications trial. The diabetes control and complications trial research group. Diabetes 1997 46 271-286.

42 Pramming S, Thorsteinsson B, Bendtson I \& Binder C. Symptomatic hypoglycaemia in 411 type 1 diabetic patients. Diabetic Medicine 1991 8 217-222. (doi:10.1111/j.1464-5491.1991.tb01575.x)

Received in final form 6 September 2016

Accepted 10 October 2016

Accepted Preprint published online 10 October 2016 http://www.endocrineconnections.org DOI: 10.1530/EC-16-0050
() 2016 The authors Published by Bioscientifica Ltd

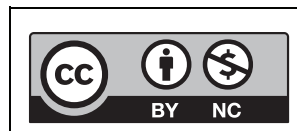

This work is licensed under a Creative Commons Attribution-NonCommercial 4.0 International License. 